UCRL- -15718

DE86 000742

R. E. Tatro

General Dynamics Space Systems Livision

T. A. Kozman

Lawrence Livermore National Laboratory

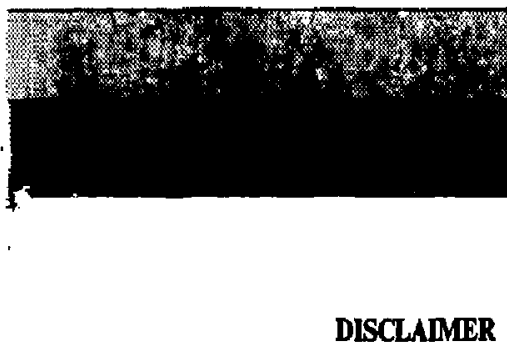

This report was prepared as an sceount of work sponsored by an agency of the United States Government. Neither the United States Government nor any areacy thereof, nor any of their employes, makes any wertanty, express or implied, or aseumes any legal liability or responibility for the accuracy, completeseas, or usefulneas of any information, apparalus, product, or procen disclowd, of represcats that its use would nol infriege privately owred tithts. Reference herein to any specific commercisl product, process, or service by trade asme, trademath manufacturer, or oherwise does pot secessurily constitute or imply is exdorsimeat, recommeadation, or farocing by the United States Gorerament or any agency thersol. The view

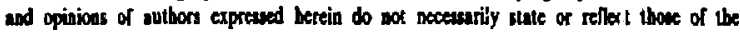
Unitod Statu Government of any agency thereof. 


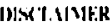

Wurh in rformed under the aupicen of tan LS. Ikpat

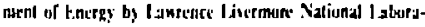

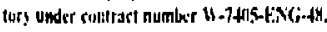

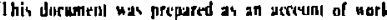

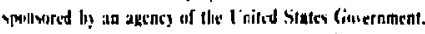

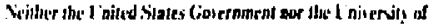

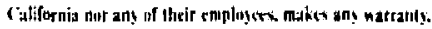
e r preas or implied, or assurases any lezal liability of Icoponvibility for the arsuracy. completemess, of usefularw uf agy informution. apparalus product. or pexces disclesed. ar represents thet its ase nould ant iafringe privalds unned

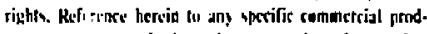

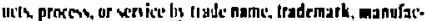

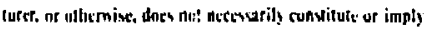
ins codursment, terenumendalion, or farniny by the l'nited States Ciurernment or the Injersity of Catifornits. The

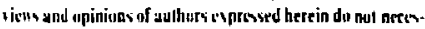

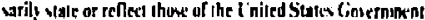

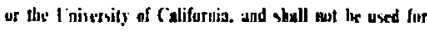
adictiving or prodect endorsentent purposes. 


\section{DESIGN AND MBRICATION OF THE MFTF-B MAGNET SYSTEM}

R.E. Thiro, Gewerd Dyonola Space Sytems bivilom

T.A. Kozmsn, Lawrence Luernore National Labordory

A.STRACT

The MFTF-g suptrodnductiog magnet syslem consists of $40 \mathrm{NbTi}$ magnets and thes Nb, Sn magnets. Geveral Dynanics (CD) vesigned all magnets exsent for the small trint soils. GD then fabricated 20 NibTj magnes, while 1.L.NL fabricaled $20 \mathrm{NbTj}$ magnets and two Nb, Sn magnets. The design phase was completed in February 1934 and included the competitive procure. nicell of mijenct siructural fabricalion, supcronductor, G-IOCR insulation, surpurl struts and bearings, npor-cooled lends, and thernal shields for als thathets. Fabricution of al] marnes was conipleted in March 1985. At CD. Wist assembly lines wete necessury during [obrication in ooder 10 meet the aggressive LLNl. schedule. The entire niagnet sysicm bes been installed and aliened al LLNL, and Tech Demo Iests will be petformed during SeptemberNiwennter 1985.

\section{INTRODUCTION}

Helore magnetically conlined nucles fusina can be conmercialized, it will be ntcessary io demondinte the ability in control the fundamenial fusion Fmicuses and welieve the requirtd letel nf performance with simplified reastur Jesigns. The Mirnor Fusion Tesi Facility (MFTF-B) is a mujor step in the tunden mifror concept and is such a machine.

The endem mitror uns conctived in 1976 and bus erolved into the curPtnI MFTF-B symmetrical magnet con/guration (Fig. 1). The plasma is continid within the long cenind cell, consinined by I welve 5.5-meier solenoids, and is then throtted by the two axicells, the secood one hrving a 12-kesla Nh, Sin inser coil. Two innsition coils conven the circulur plasma into a fan shape prior to ils entering the Yin-Ying end plugs The mojor hardware conpuncents nuw nearing comptelion are the cryogenic plan. control and diagnoslit cearer, racuum vessel, vectum pomping station, and the superconducting IItightel sytt'm. All these sysuems will be uperated and prafed during the Tich Ikema kss. Only the supertonducting nagnel syskem will be discussed threc. with emphasis an the procuremen and fahrication processes.

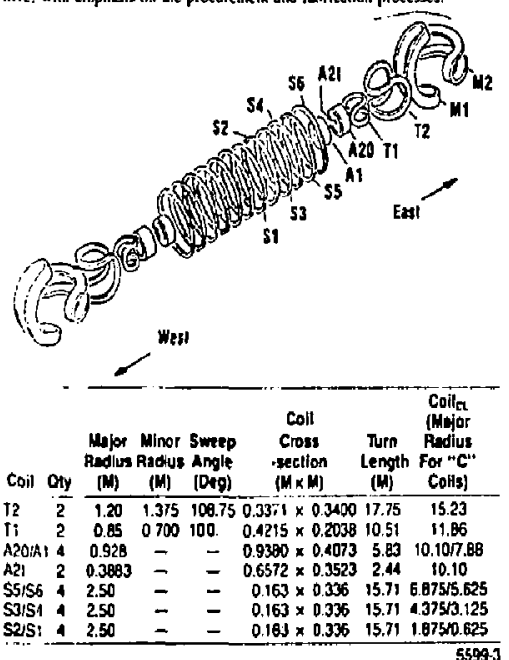

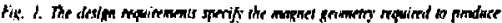
disired fiets distriburions.

General Dynamia responsibilities inclubed the design and conlirnutory anilgsis of the entire sinuturi shpport system, the $\mathrm{LN}_{2}$ and $\mathrm{H}_{1} \mathrm{O}$ thermul thiclils. and all magnets exeept the 16 trim coils. GD aso initived and Juspded all major prosuremews to wpoon these componenks. Ehbricyion of the I wu Yith-Yhing pairs, the 16 irim enils, and the ino high Jield Nb,Sa insert cuils uas iscomplished by LLNL in.housc. GD, with major support from

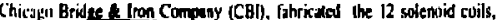
trut aricell coils, and four trasition crils in its San Diggo facility. Install]tiwn of the thermal shiedds and the magnel/support system was perfortned by L.LNL prior to and duriag meneit installation and alignment in the vessel.

This watk was performed by General Dymanics under LLNL Subconract $\Rightarrow 45 \% 309.072105$
A simplified prognm schedule is shown in Fit. 2. Bued on a fiom LLNL requirement to achiere this aperessive prognn seheduke, GD chose to facilitize and use four magnet fabriction lines. All mugnets were delivered on o before their schousule detes at slightly below cosl, I fect of which GD is extremaly proud. The performance of each magnet will be demonsirued and evalused by LLNL during the Tech Demo kess in Sepiember-Nosember of this year. The principal magnet chancleristic is magnetic field us curren. If whition, the temperature profile during cooldown and warmup and the stresses et critical locasions will be carefully monjtoned

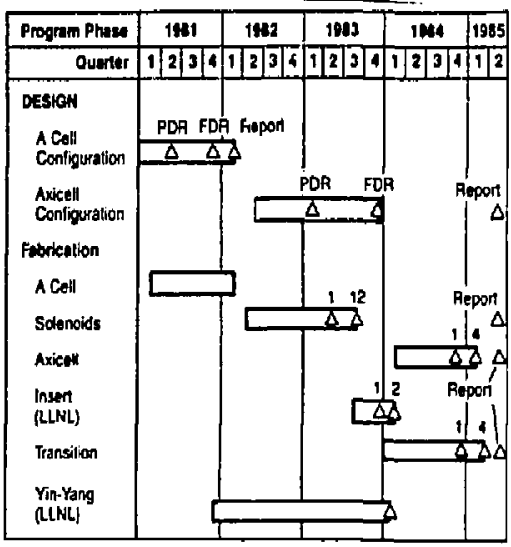

Fig. 2. MFTF. Is scterdide.

DESIGN

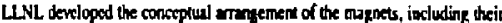
getneral configuration, spatial loctions, and the ittemil anp luras vo achiever

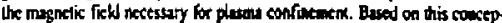
twal dra, GD performed prelininury and yes and desiga. Afer fomnl re viet and uppronl by LLNL, GD procestod with the detailed desifm and

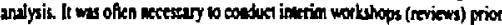
to the early procuremest of specific anjor conpowents roquired to mappon

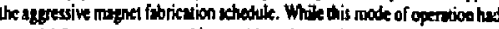
poltentill for ettor, we wert ste to webiete ote requited subconenctor deliy-

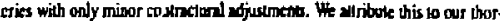
ough, curciul anslysis lexding to timely, decisive sctions by both GD and LLNL, and ba cooperative attitude and filizent atkention by most subeontrators.

Basic data for exch mignet type daigned by Geacen Dynamics is shown in Fig. L. The delailed design requ, emems were defined by LLNL in $\square$ De. sign Requiremenks Documeht. The significant tequitements wer geometry design stress, magnet hes losd limitalions, and conductor requisements.

The M1 and M2 coils hime the sane geometry as those used in the MFTF-A Yin. Yent magact. Both ate "C"-shaped coils with two mojor und

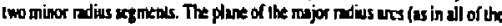

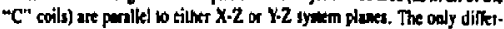

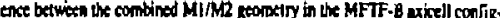
urtion and is previous MFTF-A and MFTF-B A-Ctll dhijes is in the distane betwen coils. In the axicetl cosfigurnion, the $M 1$ ind $M 2$ coils were

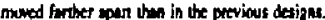

The TI and TI Innsition coils are also " $\mathrm{C}$ " coils, whose purpose is to Irasifom the plama thape, in a conitrolled manner, from the citculsr staps coning out of the axicell coils irta the fan shape tha eneers the M1/M2 Yin Hine magnets. The $\mathrm{Tl}$ and $\mathbf{1 2}$ coils differ from the $\mathrm{MI}$ and $\mathrm{M} 2$ coils in the their mujor redius arcs spen more than 180 defrees. This prodused a number af difticuli helium vemilaxion problems that were solved during the matnel uesign.

The Al and A2 axicell cuils are solenoid coils whose function is to produce high on-uis fields that form one of the barriess in the plasma containdeal syitem. The Al and A20 (oukr) coils ane identical excep for their exemd support sructures They both produce, by themselves, on-2xis field of aboux 6 lesh. The $A 2$ axicell coil, however, hes an insert coil desigraled A2l (insert) that fis inside of the Aro coil and raises this on-uxis field to 12 iesti. 
The iwetve 5.5M centrid-cell soleavid coils provich most of the plasma

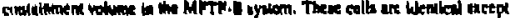

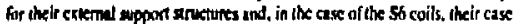
structures.

The whedule dernands kft vittually no time for develipment wusk relating to the insert eqil; so we relied on the expertise in Nbsn technology in

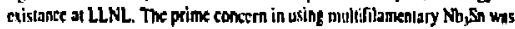
in ensure thas the conductor sibin frmm all wurces did not exeerd the allewn. ble lienits, which typically are 0.6 to 0.8 . For these coils we were tole to tinit the toral conduclos ariin to kss than $0.4 \%$, with the winding process therrihuting sout $0.3 \%$.

The Iwo MFTF. B operating modes prodere unstis field distribution whowe primary diftkreke is in the cental sell treld (i.OT bo the MARS Iniwe and $1.6 T$ for the Kelley mode). This aliso affecls the openaling curnents in the solenoids and in the axicell coils.

\section{POCUREMLEN}

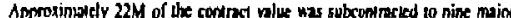
renkers (Table I). All coetrecs were fied price with deliverics timed bo suppott the GDILNL tobrication and assembly xchedule. Great care ws

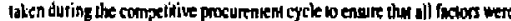
convidersd the conid allect the ability of the biskes to pertotin these tized prite procurements within the specified schedule, Whik most subcontractors cacounicred numerous defnys due vo late naterials deljery, equipment probkens, and chenges by GD, most of them performed antirbly in supporting the ispressive schadule. Al the initivion of the procurement ryck, $\mathrm{GD}$ gencrated a desailed weehnical specification in exch jueth to be proured, As is

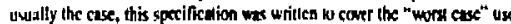
of the maleris. The GD progerm office established a procedure wherein any

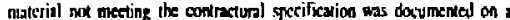
Hoiver Authorization Reguest Form (WARF) by the subcorisctot. This WhRF was then tennsmilled to the GD prigram office QA mantiger. who dirtrited the appropriate Iechnical personnel to evalune the deficiency based on the exset intendad use and placemene withia the magnet systcre. If sulfic int safety margin remained, GD accepted the questionahic item for its in. tunded use. While this proess ofiten re sulted in additional GD rccord keteping axd fatrication effort (such as euthing and splicing), we believe il was benericias to brath GD and our subcontractors. It served the purpose of shoiding rejuction of usable macrial and thus imposing additional demandi on the subximractor to repmedre and refabricalc the rejectod part. If also acsisiol GD in maintaining fabrication schelule ficxibility. In no caxe was any ilem atcepted fir use that cnmpromised the strustural inteqrity of preflosmasce of any wimpunem or system.

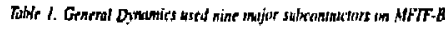

\begin{tabular}{|c|c|c|}
\hline Subeontnetor & Responsibility & $\begin{array}{c}\text { Contrici } \\
\text { Vilum } \\
(9)\end{array}$ \\
\hline $\begin{array}{l}\text { 1. Chicago Bridge \& } \\
\text { Iron Co. }\end{array}$ & $\begin{array}{l}\text { Matariat procurement \& labrication ol } \\
\text { structural components } \\
\text { Welding }\end{array}$ & $9.5 \mathrm{M}$ \\
\hline 2. Spaulding Fibre & G.1OCA insulation for all magnels & $9.7 \mathrm{M}$ \\
\hline $\begin{array}{l}\text { 3. Inteimagnetic } \\
\text { Genoral }\end{array}$ & $\begin{array}{l}\text { NbTi conductor core for axiceth a } \\
\text { iranailion mugnels }\end{array}$ & $2,2 \mathrm{M}$ \\
\hline $\begin{array}{l}\text { 4. Oxford } \\
\text { Supareconductor }\end{array}$ & $\begin{array}{l}\text { Whapping el PoTi cores for wicetis } \\
\text { transition magnets }\end{array}$ & $1.6 \mathrm{M}$ \\
\hline 5. Suparcon & $\begin{array}{l}\text { NoTi suparconductor bo sotenoid } \\
\text { magnets }\end{array}$ & $1.3 \mathrm{M}$ \\
\hline 6. Furukawa Elactric & No, Sn superconductor for insert coil & $1.4 M$ \\
\hline 7. Kobe Steet & Support struks for all magnels & $1,2 \mathrm{M}$ \\
\hline B. Muthier & Therment thisids for all magnels & $1.0 \mathrm{M}$ \\
\hline 9. Meyer Tod Co. & VCL bor all magnets & 1.04 \\
\hline
\end{tabular}

CB| uzs isponatic for all atructural fabriczion and wsembly and also hod pacestement responsibility for the 304LN tructorl stecl and the weld rit used. This echinique ws ueed to give CB! maximum contol over al

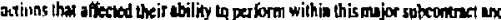
mect the fabrication whedules in uhei Sali Lake City and Biminghan fecili. tits. This action was critical to the espont of the GD cril winding and manu.

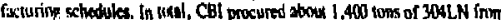
Fasit'm Stecl and performed all closent welding of the mignel cases after (ii) tourpielos the winding of the coils and instilied the plicnum insulalion. CIII also insalled all clevies for the strues.

Three types of superconductor werc procuess from four yendors. Table 2 identifies the tuagne, cosductor type, knght, ctoss-sertiona] dinensions, L, and seador. All procurements were compelitive except for the core wrap. which was a LLNLdinecled procuremcnt to utilize a LLNL-owned wrapping line at Oxford. Note that the sxicell and transition superemduclors were of the Yin-Yase lype, verying only in $L$. All supersonductors were ullivened in eptified lenglhs corresponding to their use within the mugnet. The ends of

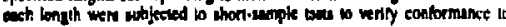
specification. OV 46 kength procused, only wo wete rejected, one for insulficiem $\mathrm{L}_{\mathrm{a}}$ and the other for soider disbond. The $\mathrm{Nb}_{3} \mathrm{Sn}$ supersonductor mantfactured by Furukawa was dinensionilly the most aceurate, varying less than mil in any dimention.

\begin{tabular}{|c|c|c|c|c|c|}
\hline Megnet & $\begin{array}{c}\text { Super. } \\
\text { condertor } \\
\text { Meterlel }\end{array}$ & $\begin{array}{c}\text { Totes } \\
\text { Footsegs }\end{array}$ & $\begin{array}{c}\text { Crots } \\
\text { Sictions } \\
\text { Oimenatons }\end{array}$ & It $4.5 \mathrm{~K}$ & Subcontinctor \\
\hline Solmolds & NbTi & 436,304 & $0.197 \times 0.492$ & $\begin{array}{c}3,400 \mathrm{at} \\
3.1 \mathrm{~T} \\
3,190 \mathrm{al} \\
3.1 \mathrm{~T}\end{array}$ & Supuicon \\
\hline Axitenll & NbTi & 158,300 & $\begin{array}{l}0.256 \times 0.256 \\
0.460 \times 0.4 \% 0\end{array}$ & $\begin{array}{c}0,930 \mathrm{~m} \\
7.5 \mathrm{~T} \\
7,200 \mathrm{nl} \\
5.1 \mathrm{~T}\end{array}$ & IGC \\
\hline Insert & $N_{b}, S n$ & 26,828 & $\begin{array}{l}0.255 \times 0.433 \\
0.043 \times 0.272\end{array}$ & $\begin{array}{r}3.200 \text { at } \\
12.75 T\end{array}$ & Furukuma \\
\hline Transition & NBTI & 105,042 & $\begin{array}{l}0.256 \times 0.258 \\
0.490 \times 0.049\end{array}$ & $\begin{array}{c}8.930 \mathrm{al} \\
7.5 \mathrm{~T}\end{array}$ & IGC \\
\hline \multirow[t]{2}{*}{ Yin. Yhang } & NoTi & 360,000 & $0.256 \times 0.250$ & $\begin{array}{c}5.775 \text { al } \\
7.5 \mathrm{~T}\end{array}$ & $\begin{array}{l}\text { IGC } \\
\text { Oxiord } \\
\text { Supereon }\end{array}$ \\
\hline & & & $0.490 \times 0.490$ & & Oxiord \\
\hline
\end{tabular}

The G-10CR procuremera was one of the moud difficult for GD to monifor and for the vender, Spanding, to perlorm, since there were many pieces of mukipk configurations. The difficulties arose duc to the GD spaification delivery schedule oy lots consisting of eppecific numbers of pieses of differen configurations. This was speciried to suppon scheduled GD magnel fabrica. tion. The vendor desired to complete the fobriention of the total required piects of a given configuration and set-up before proceding to the iteril configuretion. This uns ofien resolved by the vendor heving to vilize air ship meals on Friday ta support the nexl weet's fatrication a GD

Procurements of three components were innsferred to LLNL after conIract award, since these components were to be insalkd a LLNL after delivery of the magness by GD. They were the noorcoolad keds, the thermal shiclds, and the suppon strucs.

The vaper-coulcd leads were of the same type as previously proxured by LL.NL for the first Yin Yang. The GD.procurod leads yeried only in size and in the number of Con eubes, wrying from 14 hubes in the $\mathrm{Nb}$, Sa lead $10 \mathrm{S7}$ tubst in the $T 2$ lead.

The 90 struls comprising the aructural sopport systent for the MFTF-B were fabricated from 3aLN for the lumbutle tube and A28G for the rox enils, bearing balls, and pins. Kecte Steel ans selected to labricate and assem ble the struls, with hearings fornished oo Kobe of lesr Sictlet. Kobe was conipetitively selextrd due to bisit lotal inthouse copability. including the capsebility to make the maserials, verily the maverits propertios, and proo rest the compleet suruss before shipment.

The therm: shield system for the MFTF-B consisted of $\mathrm{LN}_{2}$ shicilds over the cilite magnet surfice, plut $\mathrm{H}_{2} \mathrm{O}$ shields between the $\mathrm{LN}_{2}$ shields and the pissm. The procurencen contistes of 2,489 paneis of 552 diflerent configurations touling 29 , $263 \mathrm{ft}^{2}$. The large number of configuntions resulted from the meerssily to moid nurnerous suy-out zones, thus forcing I cusomizing of the thichls for each mugned. This factor also mate it exirenely difficult to stundatize the shick sland-of supports. These two faters resulied in our rot whieving the desired degree of conmonality and resullod in an increased number of design drawings, a more compiter and time-coneuming fabriewion and installation monikring sydem, and many disruppions of the GD/LLNL desirtod fabrication sepuence and celuedule. All of these items contribuled to making this sabcomract with Prol Muelker Cortouny difficuls to perform.

BADTCAT10N

All NOTi magnet memufecturias ocoumed at the GD Harbor Drive fecility in Sun Dingo, CA. The manufecture of the 20 coils (12 solenoids, four axicells. and four tonsition colls) was accomplished by GD with major support from CBI. CBI fabricaled all the mugnet siruetumal components, including the cuil form, canc ctrkure sc:tions, and clevis fittings in their Salt Like City and Birmirghem facilikies. GD performed coil winding and plemom insulation

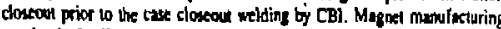
consised of: off-sile coltuponeal febrication by CBI, off-six superconducto and insulation abricution by vendors, coil brm true-up by GD, coil stownd insulation b GD, coil windins by GD, plenum insulation closeout by GD. care closeove welding by CBI $\boldsymbol{x}$ GD. clevis instalation by $\mathrm{CBI} n \mathrm{GD}$ and $L N L$, and shipment of coils by GD and LLNL. 
The lavout of the major many facturing are is shown in Fin. 3. The area

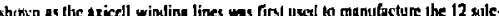

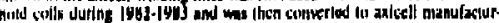
inf.

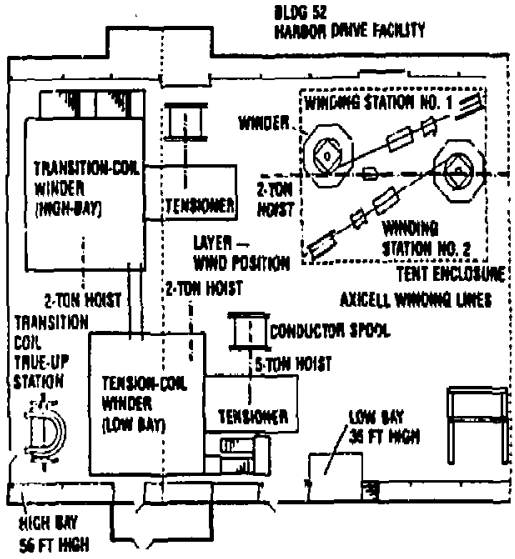

OUTHD YEST PAD

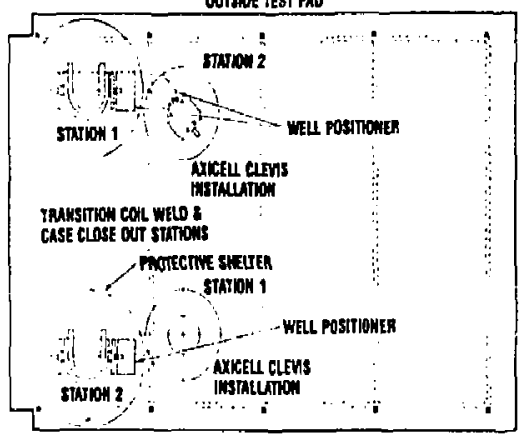

ILA 37

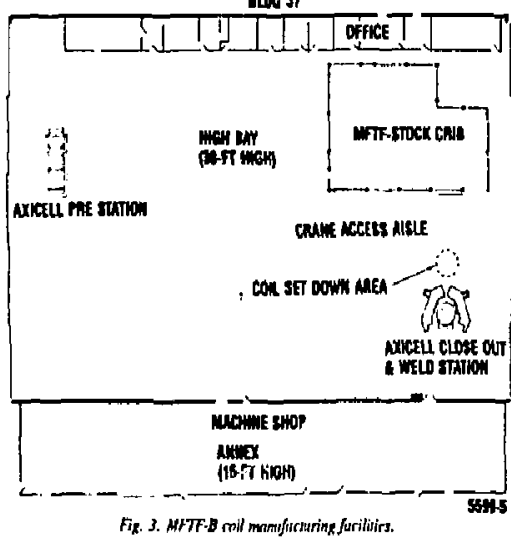

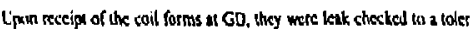
ined if $1 \times 10^{4}$ bor liken/sec at roontl kenperalure. Na kaks were ever de weted. Repair of the coil forms after winding would not be passible. The soil firms were thea trued up so that their winding cavity unuld he in a contistenl pusitisu relative to the winder. The truc-up material used was 50 parts Epon \$28 rmuly, 50 parts Vexamid hardexer, and 100 parts J/4.inch-long fiber. glass fill, Affer true-up, six layers of 1/2-mil Kupton wert applied as ground

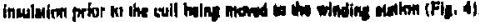

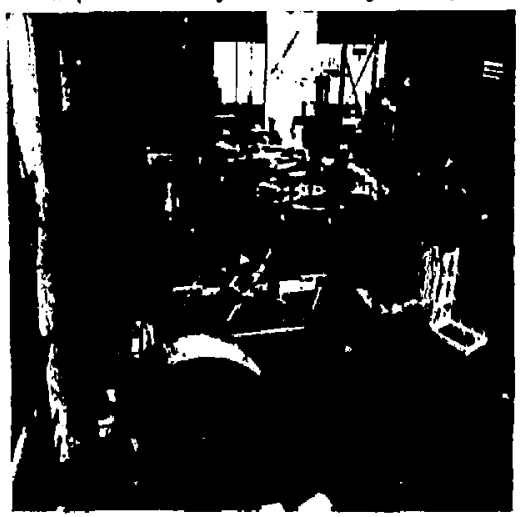

Fir. 4. Saler id coit numbing tines.

All winding was perforned wilhin 2 proctive kw, which wa meis. ained $\alpha$ s slight positive prestute usine air conditioners. Winding of the solenoids and axicells inwolved a weld positioner as the coil turniabte, an insulition batlon dispensing machining, a tensioner, a conduxior cleaning station, and a conductor reel and sland. Tro paralel winding lines were requirtid 10 mat the selteroid delivery schedule cublished by LNL. This resulked in the last raknoid being conpteted mose than three monks befort the LLNL net dak. Durios coil winding, loyer ine ( $<5$ mil) compection was achiened and maincuined with uension, lapping, and elanps. Afuer wind. ing. skoted and par forated G-10CR insulation was instulled in the coil plenum aren, resul ling in a solid pack. The seed case cover corppressed the pack and wes then welded into place by CBI.

The solenoid total fabricuion time span wenged $19 \mathrm{M}$-days and im. prowed from IBS M-days on S1 10 80 M-diys on S12. Of the $119 \mathrm{M}$-days, nine days were devoted to alignment of the coil torm on the bilding fixlure, 14 days to ine-up, 11 days for goound insuluion, 36 days for winding. 17 days tor plenum insulation, and 32 days for closecut welding.

Axicell masufaclure was basically the sane as the solenoids, except tha a single parkake wes used wo bring in the emering conductor. All solewoids and axicells were layer-wound. The axicell wotd fobriation titic span merned $155 \mathrm{M}$-days, improving from $176 \mathrm{M}$-dys on coil I (A2W) $129 \mathrm{M}$-days on coil 4 (A2E). Or the ISS days, thre days were dewowd to coil alignament on the bolding fislure, 16 doys for thxe.up, 17 day for ground insulation, 74 days for coil winding, 16 days for plenum insulution, 14 doys for case closeoul welding, and 15 dayz for clevis instalision.

A key fenture of the Harbor Drive facility was its ability to scemmodute the two lare, hewy windes and vensionen (Fis. 5) meoded to wind the four Iransition coils (two T2s and two TIs). 'The two winders were idenical in fealurea relative to platorn roution and coil (ill. wrying only in the platorm beiglk. Both winden were procured from Telodyne Reuded. LLNL procured the lower pialorm thathion to wand the two Yio-hot pain a LCNL, ater which il we diuscabled, shipped on incts in GD, and ressenbled. The use of two iransition winding stmions was also dikteded by the seed to ther

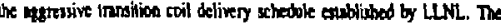
two T2 coils were wound in paraled firs, followed by the perdle] winding of the Itwo TI coils. These transition coils were alway misipned to be the moss ageressive schedule-vis, bul not wo the extenl experienced. Coil winding and plenum insulation were exch considenbly mort difikult und time consuning that the solenoids or axicetls. Difliculies were aleo experieaced die w eies. Iricat thorts in the joint are, actusive squipment breskdown, and a stike.

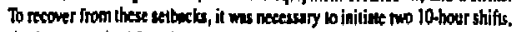
six day a mok. Aftet sis weets, this ws reluxed to no d-bour chifts, six thys a week, and aftec six more neets, we resoned our normul two thout shifis, fire doys a week.

The iola manufacturing time spon for the $\pi / 2$ coils wthped 237 M-days,

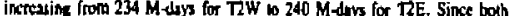
coils were beine museratured essentially in panla, lille learning is apparen. Howerer, if the $19 \mathrm{M}$-dys low due to windtr dowtitine the removed from the T2E time span, a loty of 221 M-dus resulis, which is a small improvement over the 234 days for T2W. Bou T2 coils were shipped to LLNL on the last possible day on which CD could ean the sehedule fex.

The coil manuficturing lime apen for the TI coils menged $150 \mathrm{M}$-days, improvine from 16C M dins of TIW 10134 M-day bo TIE. Experieste 


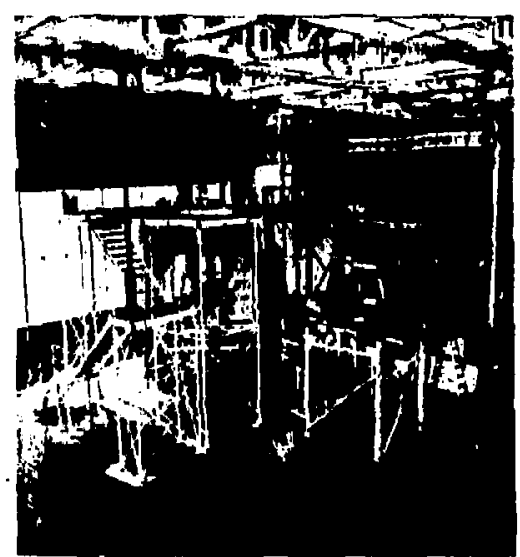

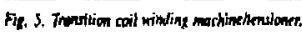

gained on the T2 coils ensoled the TI phase lo proxeed nore smoothly. Bolh TI coils were delivered significantly ahead of the requited schedule.

A LLNL winder, used to construet the Nb, Sn colis for the High Field Test facility, was modified for winding the high fiedd insen coil. A double pan. cols widd wo used, primarily to anid joists in the high field region. $A$ unique fitalurt of the Furulaw conductor wals a black oride (CuO) capling to present the soldet from wetting and coaling the areral conductor surfinces. This kechnique virtually eliminated any post-solker clean-up ard resuled in a conductor thes was abeduety free of solder lumps. This grally lacititated the winding.

\section{INSTALLATION AND ALIGNHENT}

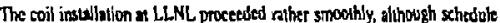
pressure tended to mate the pore hectic. The general plan in installation and alignment was fias to position the coils in the vacuum yessel. using specially designed transporters, then aftix the coils lo the vecuum ressel with the vaficus adjustablt huggers and struss, and finally move the coils into the liat poxition by jukking the trassporkers and/or ajusting the hangers and stous. The centril cell was the exceprion; in this case, 1 prir of solenoids was installed in exch section of the cemer cell vauum vessel in the magnet fabrictfiun yars. Each ressel module with the coils inside was then installed as a unit.

The rial coil position at roum tempcrattre is attually a "misaligned" pxition, which takes into wocount nolion expected during cooklown and magnet energization such thut the coils art properly positioned duning LHe Ihxeration. The required misnlignment offsels were calculated by GD for the

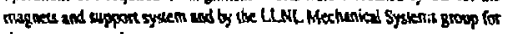
the racuum ressel.

The first coils to be irindied were the Yin-Yange These magnets, which ucighed approximalely 100 kons wilh the it is nsporters, were nowad fron the malgnel yard into the vescel building by two methads. The risst was to skid the asxembly on greased slet] plales using hydpottic fant as the driving force. and the second was to roll it onto a railer-type phalform with 144 tirts. The fint melhod, which worked well for movine the magnets dhort disunces in

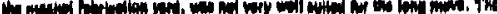

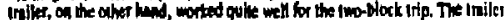

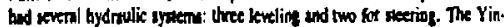
lings were polled ins the vecuun vessel acrous a bridge on a series of 100 ton Hillmus tolkan.

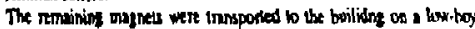
tnike. The trasition and axicell coils were installed by firs? positioning the coils on a nil sylem leading ino the vacuum vessel; rolling then into posi. tion on Hillmu rolless; and finaly insedling the stows, hangers, and links. The wolenoids wert pul directly into position with the arehend bridge crane.

Installing the axid linke runed oul to be more diffieute the oritins)

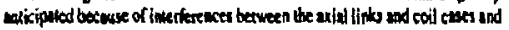

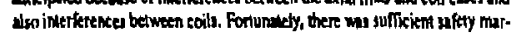
sin in the links, which allowed for mechinine to remove the interterexce.

\section{LXCONS LARWD}

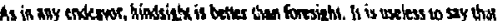
the owenill program chedule should have boen less oggrtssive, That schicduic was what the eustomer wanted and what OD agreed to meet. However, in retrospect, there ate several ilems and events thes confiem the imporanee of appruaches chosen of ofter a chance to do betier neat ime.

1. During the design phase, strive for maximetri comniondiky. This is easy

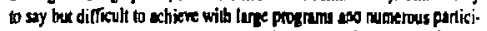

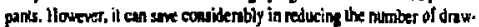
ings and results in simpletichenper proaurement and manufecturisg, with

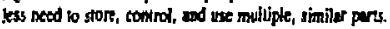

2. During the design phase, require manulacturine perononel 10 critiqux alid creluate the desigas as they erolve in onder to force the designs to reflest the simplist, most cost-effetive manufucturing techniques.

3. Review wilh all manufucturing personnal, engineers, lechnicians, and anpinkering linison whal is to be done, why it mus be done in the specitied way, and the necessity for following the apecificxions and proveders until they are officially changed.

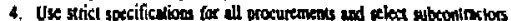
most fitely on then. Howerer, retuia the fexibiliy and willingess to recriluale be rejection or use of sub-spec manerial.

5. As a progthm oflice, tttin and do not share informetion relative 10 your financial and schalule testres.

\section{ACKNOWLEDGEMENTS}

Nonc of the Ceneral Dynamics performunct wetld be sehicved without the

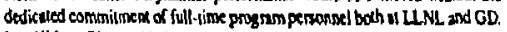
In wdition, GD prowided early, teserous support in the use of cefital equip. ment thal hes herure use on magnet progrems, 15 well as in other weas of our bosiness. WNL persoand leading the MFTF-B progen bed an unwereing

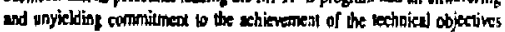
within the framework of the funding provided and the selhedule required. With these demands upon LISH, as well so upon GD, we all stceteded.

\section{AFFtrENCES}

1. MFTF-B Design Requittments Document, (revised) 15 February 1984,

2. MFTF. B Axicell Confizuralion, NbTi Nognet System, Desion und Ana]. zsis Summary, My 1985.

3. MFTF-B Axicell Configundon, Nojsn Inuert Col, Fiad Repon, March 1984.

4. NFTF-B Axicell Configusation, Thermal Libar Syetem, Find Reporl, December 1984.

5. MFTF-B Axicell Configurstion. Produsibility and Manufacturing Final Repor, May 1985 